Kualitas Visual

PADA RUANG TERBUKA PUBLIK

KAWASAN KONSERVASI ARSITEKTUR

Kajian dalam buku ini bertujuan untuk mengetahui pengaruh elemen-elemen ruang terbuka publik terhadap kualitas visual suatu kawasan terutama pada kawasan konservasi arsitektur. Untuk menjawab keingintahuan tersebut maka dilakukan penelitian di Kawasan Kota Tua Jakarta tepatnya di ruas Jalan Kali Besar Barat dan Jalan Kali Besar Timur. Hasil penelitian ini menemukan bahwa tidak dirasakan adanya faktor asimetri dan warna pada ruang terbuka publik yang ada pada lokasi tersebut. Beberapa kriteria penilaian yang digunakan, seperti: diversity, dominant, harmony, intactness, sequence, uniqueness, dan unity tidak seluruhnya berkorelasi langsung terhadap kualitas visual. Satusatunya yang dapat dirasakan pada keseluruhan elemen ruang terbuka publik yang ada hanya unity yang mempengaruhi kualitas visual sedangkan kriteria lain hanya pada elemen-elemen tertentu saja. Hal ini dapat disimpulkan bahwa ke-unity-an sangat berarti pada kualitas visual suatu ruang terbuka publik terutama di kawasan konservasiarsitektur.
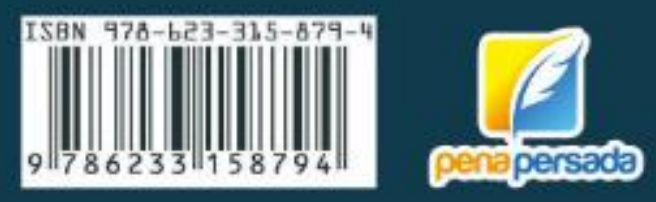

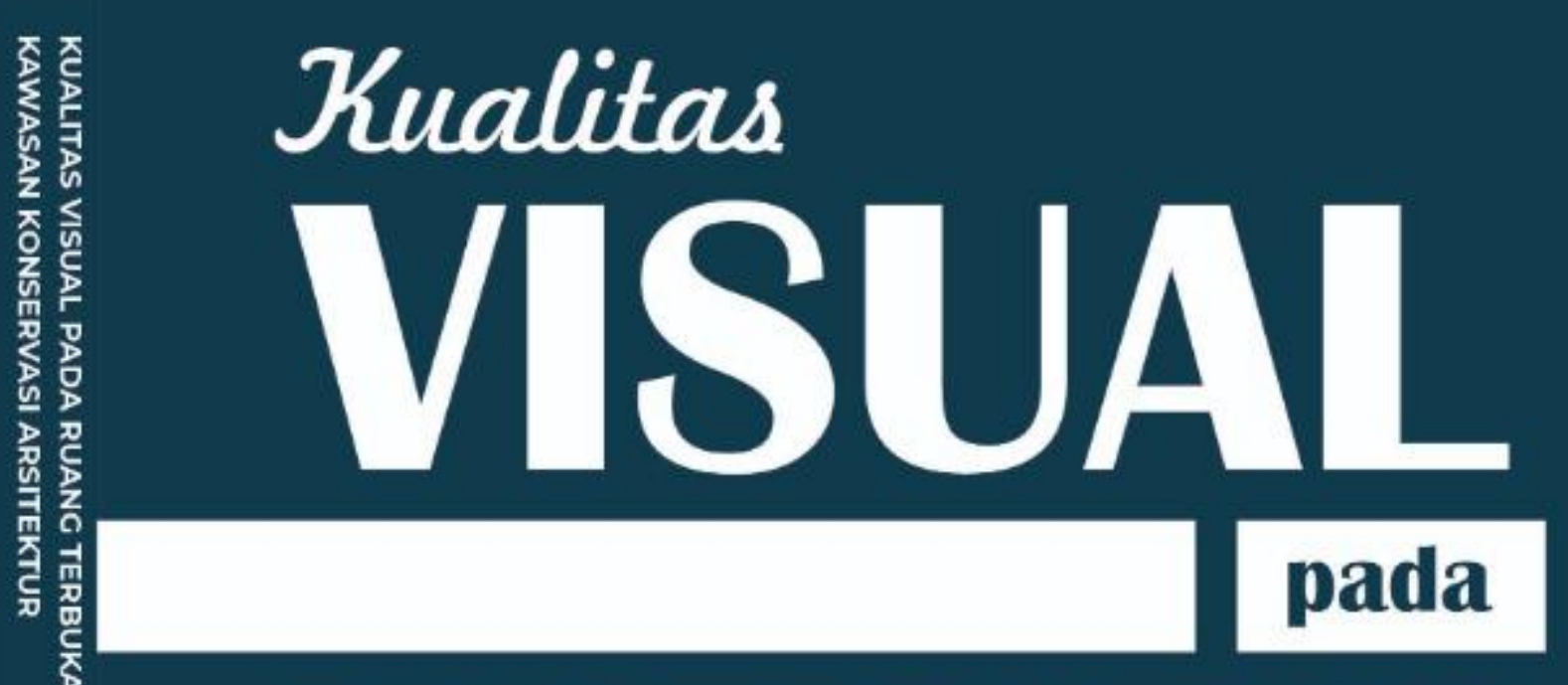

RUANG TERBUKA PUBLIK KAWASAN KONSERVASI ARSITEKTUR

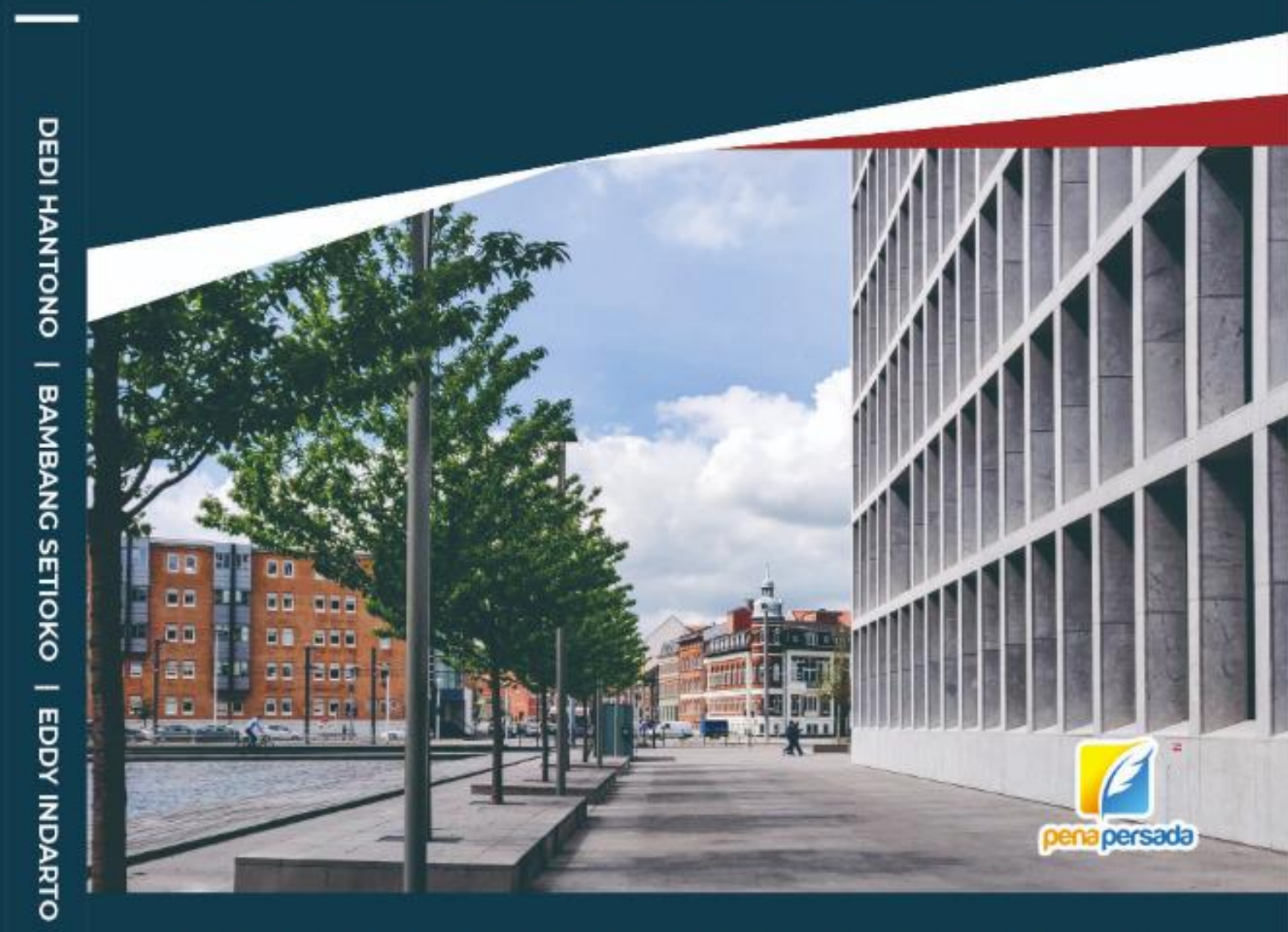

DEDI HANTONO I BAMBANG SETIOKO I EDDY INDARTO 


\title{
KUALITAS VISUAL \\ PADA RUANG TERBUKA PUBLIK \\ KAWASAN KONSERVASI ARSITEKTUR
}

\author{
Dedi Hantono \\ Bambang Setioko \\ Eddy Indarto
}

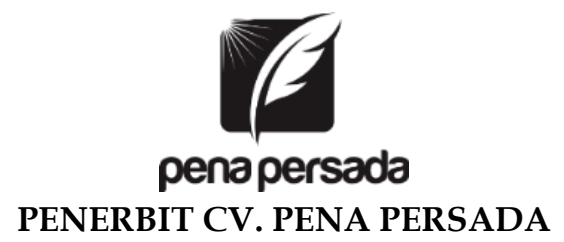




\title{
KUALITAS VISUAL PADA RUANG TERBUKA PUBLIK KAWASAN KONSERVASI ARSITEKTUR
}

\author{
Penulis:
}

Dedi Hantono

Bambang Setioko

Eddy Indarto

ISBN : 978-623-315-879-4

Editor:

Fitriani Dwi Ramadhani

\section{Design Cover :}

Retnani Nur Briliant

Layout :

Eka Safitry

\section{Penerbit CV. Pena Persada}

Redaksi :

Jl. Gerilya No. 292 Purwokerto Selatan, Kab. Banyumas

Jawa Tengah

Email : penerbit.penapersada@gmail.com

Website : penapersada.com Phone : (0281) 7771388

Anggota IKAPI

All right reserved

Cetakan pertama : 2021

Hak Cipta dilindungi oleh undang-undang. Dilarang memperbanyak karya tulis ini dalam bentuk apapun tanpa izin penerbit 


\section{KATA PENGANTAR}

Puji syukur saya panjatkan kepada Tuhan Yang Maha Esa, karena atas berkat dan rahmat-Nya, saya dapat menyelesaikan buku ini. Penulisan buku merupakan buah karya dari pemikiran penulis yang diberi judul "Kualitas Visual Pada Ruang Terbuka Publik Kawasan Konservasi Arsitektur". Saya menyadari bahwa tanpa bantuan dan bimbingan dari berbagai pihak sangatlah sulit bagi saya untuk menyelesaikan karya ini. Oleh karena itu, saya mengucapkan banyak terima kasih pada semua pihak yang telah membantu penyusunan buku ini. Sehingga buku ini bisa hadir di hadapan pembaca.

Kajian dalam buku ini bertujuan untuk mengetahui prinsip perancangan ruang publik yang dikemukakan oleh Rustam Hakim adalah: balance (simetri, asimetri, dan memusat), rhytm (garis, bentuk, tekstur, ruang, dan warna), dan emphasis, adalah tidak sepenuhnya benar pada kasus penelitian ini. Hal ini ini dapat dilihat dari jawaban responden yang tidak merasakan adanya faktor asimetri dan warna pada ruang publik yang ada di ruas Jalan Kali Besar Jakarta. Smardon (1986) berpendapat bahwa nilai visual suatu kawasan ditunjukkan oleh adanya kualitas fisik yang terbentuk oleh hubungan atau interelasi antar elemen-elemen visual pada suatu lansekap kota. Dengan kriteria penilaian sebagai berikut: diversity, dominant, harmony, intactness, sequence, uniqueness, dan unity. Keseluruhan faktor ini dapat dirasakan pada kualitas visual ruang publik, terutama unity. Hampir keseluruhan ruang publik yang ada faktor unity ini dapat dirasakan oleh para responden. Hal ini berarti mayoritas ruang publik mempengaruhi kualitas visual terutama pada faktor unity tersebut. 
Penulis menyadari bahwa buku ini masih jauh dari kesempurnaan. Oleh karena itu kritik dan saran yang membangun sangat dibutuhkan guna penyempurnaan buku ini. Akhir kata saya berharap Tuhan Yang Maha Esa berkenan membalas segala kebaikan semua pihak yang telah membantu. Semoga buku ini akan membawa manfaat bagi pengembangan ilmu di bidang arsitektur.

Jakarta, Desember 2021

Penulis 


\section{DAFTAR ISI}

KATA PENGANTAR

DAFTAR ISI

BAB 1 PENGARUH RUANG TERBUKA PUBLIK 1

A. Perkembangan Kawasan Konservasi Arsitektur 1

B. Kawasan Konservasi dan Revitalisasi 2

1. Ruang Lingkup Kajian 3

2. Diagram Alur Kajian 5

BAB 2 RUANG PUBLIK PADA KAWASAN KONSERVASI 7

A. Teori Ruang Publik 7

1. Definisi Ruang Publik 7

2. Bentuk Ruang Publik 8

3. Peran dan Fungsi Ruang Publik 8

4. Prinsip Perancangan Ruang Publik 9

B. Teori Kualitas Visual 14

1. Definisi Visual 14

2. Pembentuk Kualitas Visual 15

3. Teori Pemilihan Indikator Kualitas Visual 17

4. Persepsi Kualitas Visual 21

C. Landasan Teori dan Hipotesa 23

1. Landasan Teori 23

2. Hipotesa 24

BAB 3 ANALISIS KAJIAN KONSERVASI ARSITEKTUR 26

A. Metode Analisis Ruang Publik 26

1. Tahapan Analisis 26

2. Alat Pengumpulan Data 29

3. Populasi dan Sampel Penelitian 30

4. Variabel Penelitian 33

5. Teknik Penelitian 36 
BAB 4 DESKRIPSI KAJIAN DAN LOKASI OBJEK 38

A. Lokasi Kajian $\quad 38$

B. Objek Kajian 41

C. Segmen 1: Jalan Kali Besar Barat 42

D. Segmen 2: Jalan Kali Besar Timur 43

E. Segmen 3: Kali Besar 45

F. Segmen 4: Jalur Pedesterian Jalan Kali Besar Barat 46

G. Segmen 5: Arkade 47

H. Segmen 6: Jalur Pedesterian Jalan Kali Besar Timur (Sisi Kali) 49

I. Segmen 7: Jalur Pedesterian Jalan Kali Besar Timur (Sisi Bangunan) 50

J. Segmen 8: Area Parkir 51

K. Segmen 9: Area Taman 52

BAB 5 ANALISA DATA KAJIAN RUANG PUBLIK 53

A. Gambaran Umum Responden 53

B. Deskripsi Hasil Kuesioner 61

C. Pengujian Hipotesis 118

D. Nilai Pengaruh Variabel Bebas Terhadap Variabel Terikat dari Segmen yang Terpilih 137

BAB 6 TEMUAN PENELITIAN 142

A. Peran Elemen Pembentuk Ruang Publik Pada Lokasi Kajian 142

B. Peran Kualitas Visual Pada Kajian 146

BAB 7 PENUTUP 149

DAFTAR PUSTAKA 152 


\section{BAB 1 \\ PENGARUH RUANG TERBUKA PUBLIK}

\section{A. Perkembangan Kawasan Konservasi Arsitektur}

Jakarta sebagai kota no. 1 di Indonesia mengalami perkembangan yang paling pesat baik dari segi ekonomi, jumlah penduduk, maupun arsitekturnya. Begitu banyak gedung-gedung baru dengan bentuk yang modern menciptakan kawasan yang lebih berkualitas. Namun dibalik itu, kawasan-kawasan lama yang pernah berkembang pada masa jayanya serasa telah dilupakan. Banyak bangunan tersebut ditinggalkan sehingga menjadikan kawasan tersebut tidak berfungsi lagi, dan Kawasan Jakarta Kota adalah salah satunya.

Dulu kawasan ini dijadikan sebagai pusat pemerintahan Belanda. Hal ini ditandai dengan adanya Gedung Museum Fatahilah yang merupakan gedung pusat VOC yang dibangun pada tahun 1707. Selain itu kawasan ini merupakan kawasan pusat perdagangan dan perkantoran. Dapat dibayangkan bahwa daerah ini pada masanya sangat ramai dan strategis dalam segi ekonomi. Oleh karena sebagai pusat pemerintahan dan perkantoran serta perdagangan yang ramai tentu saja kawasan ini dipenuhi dengan bangunanbangunan berarsitektur bernilai tinggi.

Masih berada dalam Kawasan Jakarta Kota, terdapat sebuah ruas jalan yaitu Jalan Kali Besar. Ditengah-tengah jalan ini terdapat sebuah kali yang membentang dari Utara ke Selatan sehingga jalan ini terpisah menjadi 2 buah ruas jalan, yaitu Jalan Kali Besar Barat dan Jalan Kali Besar Timur. Pada abad ke-17 jalan ini merupakan pusat perdagangan yang terkenal dan dikenal dengan nama Grootegracht. Selain berisi perkantoran, pada daerah ini terdapat pemukiman etnis Cina. 
Kali ini sendiri merupakan jalur lalu-lintas kapal bongkar muat barang yang berasal dari Pelabuhan Sunda Kelapa.

Seiring dengan kesadaran akan pentingnya nilai historis bagi perkembangan kota pada masa yang akan datang, maka pada tahun 2008, pemerintah Provinsi DKI Jakarta telah mengalokasikan dana APBD untuk penataan air Kali Besar, pedesterianisasi sebagian Jalan Kunir dan pencahayaan di sekitar Sunda Kelapa, dan Museum Bahari. Khusus untuk penataan air Kali Besar, perencanaannya sudah dibuat sedemikian rupa. Kali yang selama ini difungsikan sebagai drainase dimana limbah rumah tangga langsung menuju kali tersebut, kelak tidak akan terjadi lagi. Air Kali Besar akan bebas kotoran dengan dibangunan 4 buah IPAL (Instalasi Pengelolaan Air Limbah) pada sisi kanan dan kiri Kali Besar. Debit air dijaga stabil agar pada permukaan kali tersebut kelak diselenggarakan atraksi-atraksi. Pekerjaan fisik ini sebagian besar adalah penataan infrastruktur dan ruang publik dengan tujuan menciptakan daya tarik dan menciptakan kembali kepercayaan investor utuk menanamkan modal di Kota Tua.

\section{B. Kawasan Konservasi dan Revitalisasi}

Setelah sempat terbengkalai kawasan ini mulai ditata kembali dengan dikeluarkannya beberapa peraturan dan undang-undang Gubernur DKI Jakarta yang ingin melakukan konservasi dan revitalisasi pada kawasan Jakarta Kota. Sejak ditetapkannya Kawasan Jakarta Kota sebagai kawasan konservasi dan revitalisasi, pemerintah mulai melakukan penataan kawasan terutama pada ruang publiknya. Banyak elemen-elemen ruang publik yang dibenahi, diantaranya: penertiban jalan, perbaikan jalur pedestrian, pengadaan area parkir, penambahan street furniture, dll.

Tentu saja dengan penataan kembali ruang publik membawa dampak pada perubahan fisik kawasan. Perubahan yang paling jelas terlihat adalah perubahan visual. Karena efek visual adalah hal yang pertama sekali dirasakan 
dampaknya oleh para pengamat/pengguna kawasan. Untuk itu bidang penelitian ini nantinya mengenai ruang publik dan kaitannya dengan kualitas visual.

Kawasan yang seyogyanya sudah "matang" dari segi estetika dari masa awal dibangunnya dengan langgam klasik yang begitu kental tentu menjadi prioritas utama dalam acuan menata kembali ruang publik pada kawasan tersebut. Namun kenyataannya beberapa elemen ruang publik tersebut masih terdapat beberapa permasalahan dalam kaitannya dengan sistem visual, diantaranya:

1. Perencanaan yang tidak terencana bahkan ada beberapa fungsi yang tidak terlaksana dengan baik, seperi: wisata air, parkir yang tidak terintegrasi, dll.

2. Perancangan yang tidak kontekstual terhadap lingkungan.

3. Adanya perubahan fungsi dari beberapa elemen ruang publik yang disebabkan oleh manusianya.

Banyak pekerjaan yang telah dilakukan dalam penataan ruang publik pada ruas Jalan Kali Besar Barat dan Jalan Kali Besar Timur, namun ada juga beberapa pekerjaan yang belum sepenuhnya terlaksana. Selain itu, pekerjaan yang telah ada terdapat beberapa perubahan fungsi dan kerusakan akibat kurangnya perawatan dan kesadaran masyarakat untuk ikut serta merawat fasilitas umum.

Dari uraian di atas tentu membawa dampak dan pengaruh terhadap kualitas visual kawasan. Untuk itu perlu dilakukan penelitian lebih lanjut untuk mencari beberapa penyebab permasalahan dan sampai sejauh mana tingkat kualitas visual kawasan tersebut.

\section{Ruang Lingkup Kajian}

Untuk membatasi penelitian sehingga dapat lebih terfokus pada inti permasalahan penelitian maka penelitian ini hanya melingkupi pada beberapa hal berikut: 
a. Lingkup Substansial.

Lingkup penelitian ini hanya terkait pada hal-hal arsitektur saja terutama ruang publik. Sedangkan bagian-bagian lainnya menjadi pelengkap dan memperkaya hasil penelitian.

b. Lingkup Spasial.

Lokasi penelitian berada di sepanjang koridor Jalan Kali Besar Barat dan Kali Besar Timur yang terletak pada Provinsi DKI Jakarta, Wilayah Kota Jakarta Barat, Kecamatan Tambora, dan Kelurahan Roa Malaka, atau seperti yang terlihat pada gambar berikut:

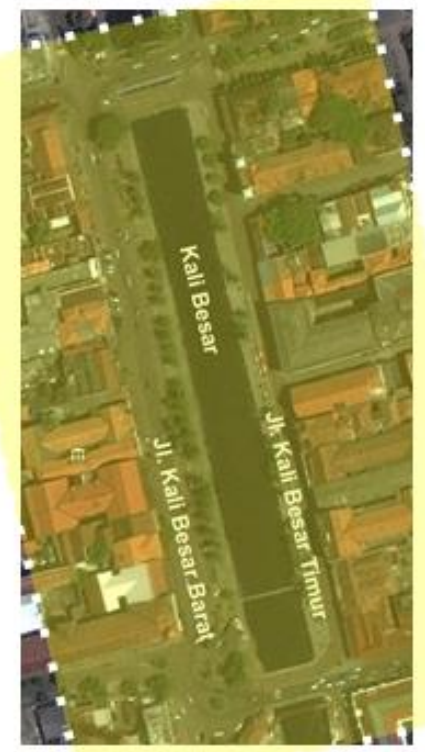

\section{Gambar 1. 1 Lokasi Penelitian}

Jalan Kali Besar Barat dan Jalan Kali Besar Timur adalah satu ruas jalan yang dibelah oleh sebuah Kali Besar yang memanjang Utara-Selatan. Sesuai dengan namanya, Jalan Kali Besar Barat adalah ruas jalan yang terdapat pada sisi Barat dari Kali Besar dan Jalan Kali Besar Timur berada di sisi Timur Kali Besar. 

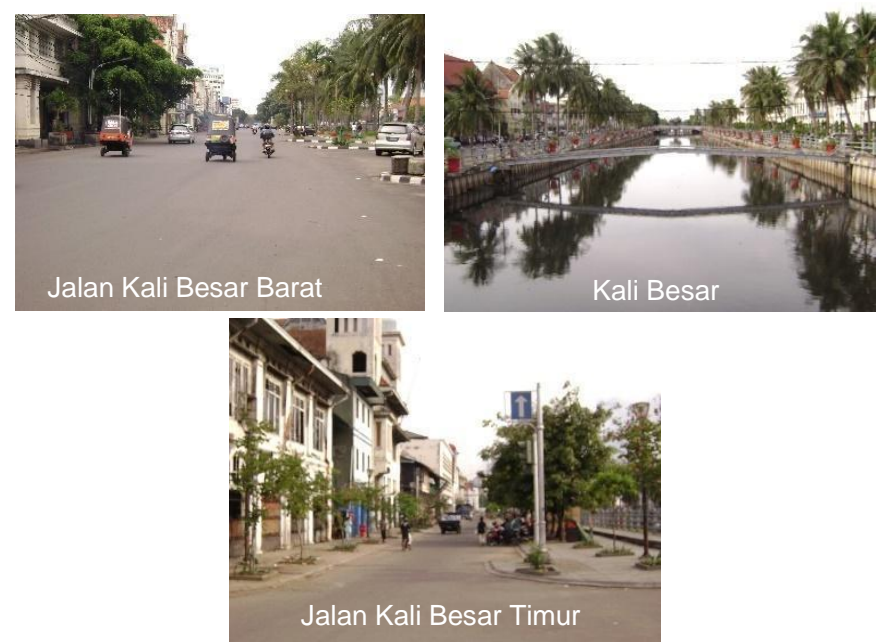

\section{Gambar 1.2 Gambaran Umum Jalan Kali Besar Barat, Kali Besar, dan Jalan Kali Besar Timur}

Lokasi penelitian berada dalam Kawasan Jakarta Kota yang merupakan kawasan konservasi dan revitalisasi. Banyak bangunan peninggalan era kolonial Belanda dalam kondisi yang terbengkalai bahkan rusak dan diganti dengan bangunan baru.

\section{Diagram Alur Kajian}

Sebelum penelitian lebih lanjut untuk dilaksanakan maka dibuat diagram alur penelitian. Diagram ini merupakan grand concept yang akan memudahkan peneliti dalam melakukan proses penelitian dari awal hingga akhir penelitian.

Penelitian diawali dengan adanya latar belakang dan fenomena yang terjadi. Kemudian diambil kesimpulan sementara (hipotesa) yang memerlukan penelitian lebih lanjut. Dari permasalahan yang ada dapat ditentukan pendekatan dan metode penelitian yang dapat memecahkan permasalahan. Kemudian dicari teori-teori 
yang relevan dan observasi pada lokasi penelitian. Guna mendukung data yang ada diperlukan juga pendapat dari para pengguna lokasi penelitian. Pertanyaan yang diajukan dalam bentuk kuesioner yang dibagikan secara langsung kepada responden di lokasi penelitian. Lalu seluruh data ini dianalisis sehingga didapat kesimpulan apakah ada pengaruh ruang publik terhadap kualitas visual pada ruas Jalan Kali Besar Barat dan Jalan Kali Besar Timur. Dan pada akhirnya dibuat rekomendasi yang dapat bermanfaat dan demi peningkatan kualitas kawasan.

Untuk dapat memahami alur penelitian tersebut dapat dilihat dalam diagram berikut ini:

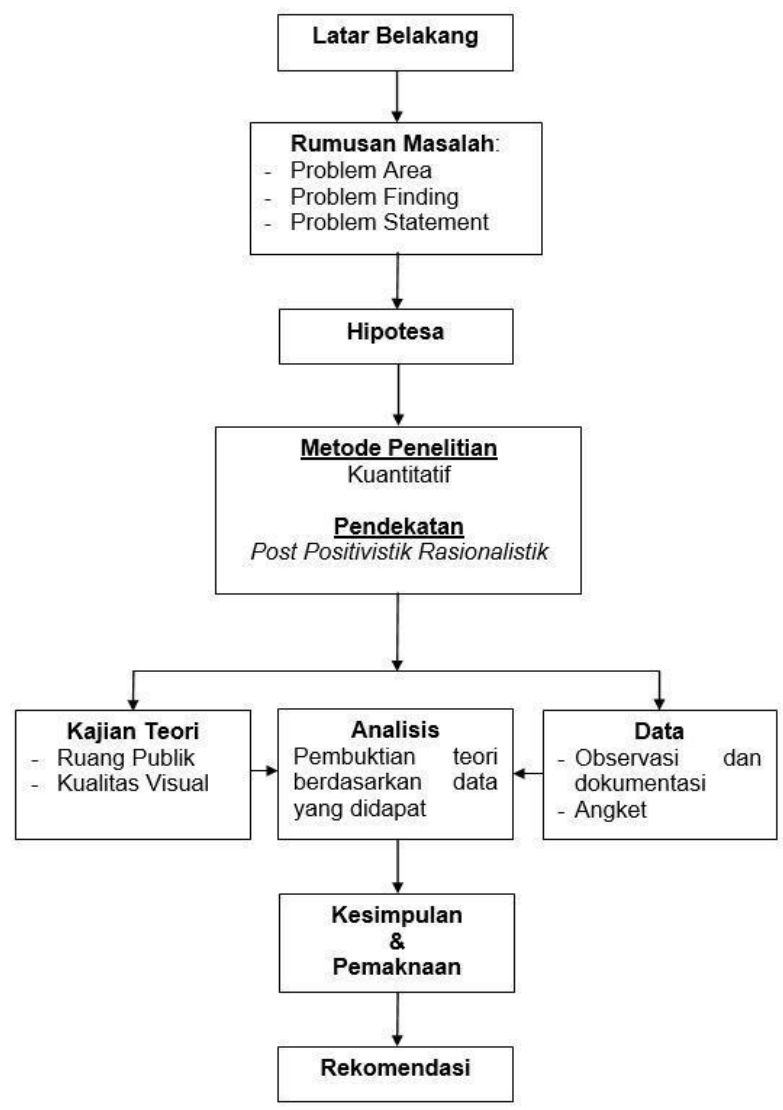

Gambar 1.3 Diagram Alur Penelitian 


\section{BAB 2 \\ RUANG PUBLIK PADA KAWASAN \\ KONSERVASI}

\section{A. Teori Ruang Publik}

\section{Definisi Ruang Publik}

Ruang adalah suatu wadah yang tidak nyata namun bisa dirasakan keberadaannya oleh manusia. Sedangkan menurut Plato dalam Eko Budihardjo (2009) ruang adalah suatu wadah dimana objek dan kejadian tertentu berada (Budihardjo \& Sujarto, 2009).

Ruang publik adalah ruang yang terbentuk karena adanya kebutuhan akan perlunya suatu tempat untuk bertemu atau berkomunikasi antara satu manusia dengan manusia lainnya. Dengan adanya pertemuan maka kemungkinan akan timbul bermacam-macam kegiatan pada ruang umum tersebut (Aziza, 2020). Dengan demikian dapat dikatakan pula bahwa ruang publik merupakan ruang yang dapat menampung aktifitas tertentu oleh manusia baik secara individu maupun kelompok (Hakim \& Utomo, 2004).

Menurut Carr (1992) bahwa ruang publik adalah suatu tempat dimana terjadinya kehidupan secara bersama. Jalan, lapangan, dan taman kota ikut memberi bentuk dari pasang-surutnya kehidupan manusia. Ruang yang dinamis tersebut adalah nilai lebih pada suatu area hunian serta kehidupan dan pekerjaan yang serba rutinitas, mewadahi kegiatan, pusat komunikasi, dan ruang bersama untuk bermain dan bersantai (Carr et al., 1992). Sedangkan menurut Rob Krier (1979), mengartikan ruang publik suatu ruang yang berada diantara bangunanbangunan perkotaan maupun daerah. Disini Krier lebih 
senang menyebutkan ruang publik sebagai ruang kota (Krier, 1979).

Dari beberapa pengertian tersebut di atas dapat disimpulkan bahwa pengertian dari ruang publik adalah ruang terbuka yang berada di luar bangunan yang dapat dipergunakan oleh manusia baik secara individu maupun berkelompok untuk melakukan aktifitas sehari-hari, seperti: berjalan kaki, berolah-raga, rekreasi, sosialisasi, dan lain-lain.

\section{Bentuk Ruang Publik}

Menurut Rob Krier (1979), ruang publik dapat diklasifikasikan atas 2 jenis, yaitu:

a. Bentuk memanjang (the street), mempunyai batas pada kedua sisi yang memiliki dimensi lebih panjang dari sisi lainnya, seperti: jalan, sungai, dll.

b. Bentuk persegi (the square), memiliki batas pada seluruh sisi yang cenderung sama ukurannya sehingga lebih dapat dirasakan sebagai bidang ruang.

Secara karakteristik geometris keduanya memiliki bentuk yang sama. Yang membedakannya adalah ukuran yang membatasi mereka serta pola fungsi dan sirkulasinya. Rustam Hakim (2004) berpendapat bahwa ruang publik dapat digolongkan atas 2 bentuk, yaitu:

a. Ruang Publik Tertutup, yaitu ruang publik yang terdapat di dalam bangunan.

b. Ruang Publik Terbuka, yaitu ruang publik yang terdapat di luar bangunan.

Dari sifat ruang tersebut di atas maka ruang publik pada umumnya identik dengan ruang terbuka.

\section{Peran dan Fungsi Ruang Publik}

Rustam Hakim mengatakan bahwa ruang terbuka memiliki 2 fungsi, diantaranya: 
a. Fungsi Sosial.

1) Sebagai tempat bermain dan berolahraga.

2) Sebagai tempat bermain dan sarana olahraga.

3) Sebagai tempat komunikasi sosial.

4) Sebagai tempat peralihan dan menunggu.

5) Sebagai tempat untuk mendapatkan udara segar.

6) Sebagai sarana penghubung antara satu tempat ke tempat lainnya.

7) Sebagai pembatas antar massa bangunan.

8) Sebagai sarana penelitian dan pendidikan serta penyuluhan bagi masyarakat untuk membentuk kesadaran lingkungan.

9) Sebagai sarana untuk menciptakan kebersihan, kesehatan, keserasian, dan keindahan lingkungan.

b. Fungsi Ekologis.

1) Sebagai penyegar udara, mempengaruhi dan memperbaiki iklim mikro.

2) Sebagai penyerap air hujan.

3) Sebagai pengendali banjir dan pengatur tata air.

4) Sebagai pemelihara ekosistem tertentu dan perlindungan plasma nutfah.

5) Sebagai pelembut arsitektur bangunan.

Edy Darmawan (2005) mengatakan bahwa terdapat 3 fungsi ruang publik. Selain sebagai fungsi sosial dan ekologi, ruang publik juga memiliki nilai ekonomi terutama bagi pedagang sektor informal (Darmawan, 2005).

\section{Prinsip Perancangan Ruang Publik}

Prinsip perancangan adalah dasar dari terwujudnya suatu ciptaan bentuk. Bentuk itu sendiri terdiri dari beberapa unsur atau elemen yang masing-masing memiliki sifat dan karakter tersendiri. Untuk menyatukan hal tersebut diperlukan prinsip desain yang matang, yaitu: keteraturan (consistency) dan kesatuan (unity). Keteraturan diperoleh melalui pendekatan tema rancangan sedangkan 
kesatuan melalui penyederhanaan unsur serta memperkecil perbedaan antar sesama unsur-unsur tersebut.

Untuk mencapai keteraturan dan kesatuan tersebut perlu diperhaikan beberapa hal yang harus dicapai, diantaranya:

a. Keseimbangan (Balance).

Keseimbangan dalam rancangan berarti penyamaan tekanan visual suatu komposisi antara masing-masing unsur. Susunan yang tidak seimbang akan menimbulkan konflik dari sudut visual. Bentuk keseimbangan ini dapat berupa :

1) Keseimbangan simetris.

Unsur-unsur disusun dalam komposisi yang sama antara kedua sisi. Keseimbangan dalam bentuk ini bersifat statis, formal, kaku, agung, dll.

2) Keseimbangan asimetris.

Unsur-unsur disusun dalam komposisi yang tidak sama namun tetap dalam prinsip rancangan yang baik. Keseimbangan dalam bentuk ini lebih bersifat dinamis, gerak, spontan, informal (santai), dll. Asimetris juga melambangkan kebebasan ekspresi.

3) Keseimbangan memusat.

Keseimbangan ini memberikan kesan gerak ke satu titik.

Menurut Rob Krier (2001) untuk membangun keseimbangan peran simetri harus jauh lebih dominan daripada simetri. Hal ini berdasarkan kondisi alamiah yang lebih cenderung kepada halhal yang simetris. Anatomi makhluk hidup bila dilihat dari depan terlihat simetris namun jika dilihat dari samping kelihatan asimetris. Walaupun demikian kesan simetris secara keseluruhan lebih mendominasi (Krier, 2001). 
b. Irama dan Pengulangan (Rhytm and Repetition).

Irama adalah pengulangan unsur yang dipergunakan pada tempat yang berbeda dan membentuk ikatan atau hubungan visual. Dalam perancangan ruang luar, irama diperoleh melalui:

1) Garis, yaitu suatu rupa yang menghubungkan 2 buah titik. Garis terbagi atas 2 macam, yaitu: garis lurus dan garis lengkung. Garis lurus itu sendiri terdiri dari 3 macam, yaitu: vertikal, horisontal, dan diagonal. Masing-masing garis memiliki sifat, karakter, dan kesan yang berbeda. Garis vertikal memberikan kesan kaku, gagah, tinggi, dll. Garis horizontal meberikan kesan lebar, santai, tenang, dll. Garis diagonal memberikan kesan dinamis, menarik perhatian, bergerak, dll. Sedangkan garis lengkung memberi pengaruh gembira, fleksibel, lembut, dll. Pada umumnya garis lengkung lebih tepat untuk aplikasi ruang yang tidak formal, santai, rekreasi, dll.

2) Bentuk, yaitu wujud suatu benda, baik dalam 2 dimensi maupun 3 dimensi. Bentuk bisa dalam bentuk beraturan maupun bentuk tidak beraturan. Bentuk beraturan adalah bentuk geometris dasar yang bisa dikenali wujudnya, seperti : segitiga, segi empat, lingkaran, kotak, bola, dll) sedangkan bentuk tak beraturan adalah bentuk hasil dari perkembangan atau kombinasi dari bentuk geometris yang ada.

Pada tata ruang, pengolahan bentuk dapat mempengaruhi kesan ruang. Bentuk geometri dasar (persegi/kotak, segitiga/pyramid, lingkaran/bola, dll) lebih bersifat statis. Sedangkan bentuk tidak beraturan mengambarkan sifat dinamis dan kebaruan. 
3) Tekstur, yaitu kualitas permukaan suatu bidang (halus-kasar).

Tekstur pada ruang luar sangat erat hubungannya dengan jarak pandang (visual). Semakin jauh jarak pengamat dengan obyek yang diamati maka semakin tidak terlihat tekstur benda tersebut hingga pada jarak tertentu obyek tersebut terlihat polos tanpa tekstur. Oleh karena itu tekstur dapat dibedakan atas 2 macam, yaitu:

- Tekstur primer, yaitu tekstur yang melekat pada bidang permukaan obyek tersebut.

- Tekstur skunder, yaitu tekstur yang dibuat untuk tujuan agar dapat terlihat pada jarak tertentu untuk memberikan kesan visual yang diinginkan, contoh: unit-unit beton cetak disusun pada dinding membentuk pola tertentu dan pada sambungan antar unit beton tersebut digunakan bahan metal sehingga pada jarak tertentu pola tersebut masih kelihatan sebagai tekstur permukaan dinding tersebut.

4) Ruang, yaitu suatu wadah dimana objek dan kejadian tertentu berada. Secara fisik ruang dibentuk oleh 3 elemen dasar, yaitu: alas, dinding, atap.

5) Warna, yaitu corak/intensitas permukaan suatu bentuk. Warna merupakan atribut yang paling mencolok yang membedakan suatu bentuk dengan lingkungannya. Warna bisa didapat melalui pewarnaan buatan (pengecatan) maupun alami (berasal dari benda itu sendiri, seperti hijaunya tanaman).

Prang dalam Rustam Hakim (2004) membagi adanya kelas warna sebagai berikut:

- Primary, yaitu warna utama, yaitu: merah, kuning, dan biru. 
- Binary, campuran dari 2 warna primary, seperti: merah + kuning $=$ jingga, biru + kuning $=$ hijau .

- Intermedian, campuran dari warna primary dan binary, seperti: merah + hijau = merah kehijauan.

- Tertiary, campuran dari 2 warna binary, seperti: jingga + hijau.

- Quanternary, campuran dari 2 warna tertiary, seperti: hijau oranye + violet oranye.

Komposisi warna memiliki 2 sifat, diantaranya:

- Keselarasan yang Berhubungan.

Keselarasan ini dicapai melalui warna-warna yang berhubungan, seperti: monokromatik dan analogus.

- Keselarasan yang Tidak Berhubungan.

Keselarasan yang dicapai melalui warna-warna yang sederajat, seperti: komplementer dan polikromatik.

Warna dapat menimbulkan efek psikologis tertentu, seperti: luas-sempit, gembira-sedih, hangat-dingin, berat-ringan, dan sebagainya.

c. Penekanan dan Aksentuasi (Emphasis).

Penekanan dapat diartikan suatu upaya untuk menonjolkan salah satu komponen agar tampak terlihat lebih menonjol dibandingkan komponen lainnya atau dengan kata lain adanya dominasi salah satu komponen sehingga menimbulkan kontras terhadap komponen lainnya. Dengan begitu penekanan dipergunakan sebagai titik pusat perhatian kepada satu komponen sedangkan komponen lainnya sebagai unsur penunjang.

Penekanan bisa melalui ukuran, tata letak, bentuk, warna, dan lain-lain. Dengan demikian melalui ukuran, tata letak, bentuk, warna tersebut dapat menjadi unsur utama dalam menarik perhatian para pengamat. 